\title{
The oral manifestations of scurvy in the 21st century
}

\author{
Manifestações orais do escorbuto no século 21 \\ Las manifestaciones orales del escorbuto en el siglo XXI
}

Recebido: 13/09/2021 | Revisado: 17/09/2021 | Aceito: 21/09/2021 | Publicado: 23/09/2021

Claudia Carrara Cotomacio ${ }^{1}$

ORCID: https://orcid.org/0000-0002-2659-4703

Paulista University, Brazil

Universidade Federal de São Paulo, Brazil

E-mail: claudiacotomacio@graacc.org.br

Luana Campos

ORCID: https://orcid.org/0000-0002-2747-2812

University of Santo Amaro, Brazil

E-mail: lucampos@prof.unisa.br

Fabiana Martins

ORCID: https://orcid.org/0000-0002-4352-7959

University of Santo Amaro, Brazil

E-mail: fmoliveira@prof.unisa.br

\begin{abstract}
Scurvy is a vitamin deficiency historically associated with pirates and sailors that affects collagen synthesis, leading to hemorrhage, skin, and oral lesions. In the 18th century, the lack of consumption of foods rich in vitamin $\mathrm{C}$ was found to cause such a severe condition, whose early diagnosis increases the likelihood of a better prognosis. A 58-year-old female patient complained of fatigue, body pain, and gingival bleeding for nearly 24 months. In 2001, she was diagnosed with lupus, now in remission, and osteoporosis more recently. On clinical examination, gingivitis with spontaneous bleeding was observed, despite the patient's good hygiene, as well as some petechiae over the body. Due to the hypothesis of a possible autoimmune dermatological disease, the patient was referred to a dermatologist, who requested a series of tests, including vitamin $\mathrm{C}$ dosage. The results showed a concentration below $0.25 \mathrm{mg} / \mathrm{dL}$ (IR, 4 to $2.0 \mathrm{mg} / \mathrm{dL}$ ), and thus the diagnosis of scurvy was established. The patient was administered vitamin $\mathrm{C}$ replacement and in about 3 months, the symptoms started to improve. In some cases, such as this, hospitalization is required for intravenous replacement due to bleeding risks. This case report highlights the importance of the dentist in the early diagnosis and treatment of scurvy. This condition causes oral lesions that are often confused with other more common conditions, such as gingivitis or autoimmune dermatological response. Therefore, we recommend a comprehensive physical examination and anamnesis, including dietary history.
\end{abstract}

Keywords: Scurvy; Oral manifestations; Ascorbic acid; Gingivitis; Avitaminosis.

\section{Resumo}

O escorbuto é uma deficiência vitamínica historicamente associada a piratas e marinheiros, a qual afeta a síntese de colágeno, levando a hemorragias, lesões cutâneas e orais. No século 18 , constatou-se que a falta de consumo de alimentos ricos em vitamina $\mathrm{C}$ causava esse quadro grave, cujo diagnóstico precoce pode aumentar a probabilidade de um melhor prognóstico. Uma paciente do sexo feminino, 58 anos, com queixa de fadiga, dores no corpo e sangramento gengival há quase 24 meses. Em 2001, ela foi diagnosticada com lúpus, agora em remissão, e osteoporose mais recentemente. Ao exame clínico, observou-se gengivite com sangramento espontâneo, apesar da boa higiene da paciente, além de algumas petéquias pelo corpo. Devido à hipótese de uma possível doença dermatológica autoimune, o paciente foi encaminhado a um dermatologista, que solicitou uma série de exames, incluindo dosagem de vitamina C. Os resultados mostraram concentração abaixo de $0,25 \mathrm{mg} / \mathrm{dL}$ (RI, 4 a 2,0mg / dL), estabelecendo assim o diagnóstico de escorbuto. O paciente recebeu reposição de vitamina $\mathrm{C}$ e, em cerca de 3 meses, os sintomas começaram a melhorar. Em alguns casos, como este, é necessária hospitalização para reposição intravenosa devido ao risco de sangramento. Este relato de caso destaca a importância do dentista no diagnóstico precoce e tratamento do escorbuto. Essa condição causa lesões orais que costumam ser confundidas com outras doenças mais comuns, como gengivite ou resposta dermatológica autoimune. Portanto, recomendamos um exame físico abrangente e anamnese, incluindo história alimentar.

Palavras-chave: Escorbuto; Manifestações bucais; Ácido ascórbico; Gengivite; Deficiência de vitaminas.

\section{${ }^{1}$ Correspondence:}

Claudia Carrara Cotomacio. E-mail: claudiacotomacio@graacc.org.br.

Pediatric Oncology Institute/GRAACC, Department of Dentistry

R. Pedro de Toledo, 571 - Vila Clementino, São Paulo - SP, 04039-001 - Phone: +55 11 5080-8438 


\begin{abstract}
Resumen
El escorbuto es una deficiencia de vitaminas históricamente asociada con piratas y marineros, la cual afecta la síntesis de colágeno, provocando hemorragias, lesiones cutáneas y orales. En el siglo XVIII, se descubrió que la falta de consumo de alimentos ricos en vitamina $\mathrm{C}$ provocaba esta grave afección, cuyo diagnóstico precoz aumenta la probabilidad de un mejor pronóstico. Una paciente de 58 años se quejó de fatiga, dolor corporal y sangrado gingival durante casi 24 meses. En 2001, le diagnosticaron lupus, ahora en remisión, y osteoporosis hace un mes. En el examen clínico, se observó gingivitis con sangrado espontáneo, a pesar de la buena higiene de la paciente, así como algunas petequias en su cuerpo. Ante la hipótesis de una posible enfermedad dermatológica autoinmune, la paciente fue referida a un dermatólogo para una serie de pruebas, incluida la dosificación de vitamina C. Los resultados mostraron una concentración por debajo de 0,25 mg / dL (RI, 4 a 2,0 mg / dL), por lo que se estableció el diagnóstico de escorbuto. La paciente fue tratada con reemplazo de vitamina $\mathrm{C}$ y, en aproximadamente 3 meses, los síntomas comenzaron a mejorar. En algunos casos, como este, se requiere hospitalización para el reemplazo intravenoso debido a los riesgos de hemorragia. Este caso clínico destaca la importancia del odontólogo en el diagnóstico y tratamiento precoz del escorbuto. Esta afección provoca lesiones orales que frecuentemente se confunden con otras afecciones más comunes, como la gingivitis o la respuesta dermatológica autoinmune. Por lo tanto, recomendamos un examen físico completo y una anamnesis, incluida la historia dietética.
\end{abstract}

Palabras clave: Escorbuto; Manifestaciones bucales; Ácido ascórbico; Gingivitis; Avitaminosis.

\title{
1. Introduction
}

Scurvy was first-time described in 1500 b.C. as a disease typical of pirates and sailors, which affected mostly gums and skin. In the XVIII century, physicians observed the association between the lack of consumption of citric fruits during ship travels and this condition (Gutierrez and Martinez-Mier, 2019).

Vitamin $\mathrm{C}$ or ascorbic acid is present mostly in fresh fruits and vegetables, an essential vitamin for collagen production, an essential component of several connective tissues. Vitamin $\mathrm{C}$ allows hydroxylation of specific sites of procollagen to final collagen formation. In that way, a lack of vitamin $\mathrm{C}$ (or ascorbic acid) intake leads to inhibition of various types of collagen production found in skin, blood vessels, and gum (Gutierrez and Martinez-Mier, 2019; Semba, 2008).

After 8 to 12 weeks, the vitamin $\mathrm{C}$ deficiency presents some symptoms that vary from poor wound healing, gingival swelling with possible loss of teeth, mucocutaneous petechiae, ecchymosis, and hyperkeratosis organ hemorrhage and rheumatologic findings (Maxfield and Crane, 2020). In a study with monkeys, showed that vitamin deficiency present signals linked to gingivitis - redness, easy bleeding, and inflamed gums (Alvares and Siegel, 1980; Kern and Gardner, 2020). However, it is important to highlight that avitaminosis does not cause periodontal disease (Touyz, 1984).

Although scurvy is an XVIII century disease, some habits can currently lead to this condition (Callus et al., 1984). Risk factors to scurvy development include alcoholism, poor diet in fruits and vegetables (Ceglie et al. 2018), smokers, eating disorders, diabetes type I, inflammatory bowel disease, iron overload, and restrictive diets due to food allergies (Maxfield and Crane, 2020). The treatment consists of vitamin C reposition, and the side effects tend to regress after three months (Maxfield and Crane, 2020; Shaikh et al., 2019).

In addition, it is noteworthy that, when associated with other systemic diseases, such as autoimmune inflammatory ones (eg. Lupus), which can also affect multiple organs and tissues, such as skin, joints, kidneys, and brain; makes it even more difficult to diagnose and manage the patient (Morel, 2017; Likhitweerawong, et al. 2021). However, although scurvy can cause some rheumatologic alterations, there are no cases on scurvy described in lupus patients reported in the literature. The present study reports a case of oral alterations due to vitamin $\mathrm{C}$ deficiency in a patient with lupus.

\section{Methodology}

A Patient Informed Consent Term was obtained to use clinical images of the case in scientific publication. This study is case study research of qualitative and descriptive nature, in which was showed a case of unusual scurvy oral manifestation 
(Pereira et al., 2018), carried out in private practice in the city of Barueri - SP - Brazil. All steps of anamnesis, clinical examination, diagnostic hypotheses, final diagnostic, treatment, and case outcomes were described in case report session.

\section{Case Report}

A 58-year-old woman was referred to the clinical practice complaining about fatigue, body ache, and swollen, painful, and bleeding gums for almost a year. The patient was diagnosed with lupus in 2001 (now in remission) and osteoporosis one month ago.

During the interview, the patient revealed that she was allergic to papaya, fig, coconut water, eggplant, and to several drugs, including antidepressants (venlafaxine), analgesics (meperidine, dipyrone), anti-inflammatory (ketoprofen, tenoxicam, sodium diclofenac), muscle relaxant, antibiotic (amoxicillin, xylocaine) and preservatives. The patient denied a poor diet in fruits and vegetables because followed a diet described by a nutritionist.

The patient has been treated with hydroxychloroquine 400mg 3 times per week for lupus condition and ritmonorm 300mg 1 time per day for cardiac arrhythmia. On clinical examination, was observed spontaneous bleeding and gingivitis, despite good oral hygiene (Figure 1). On radiographic examination, some bone reabsorption was observed (Figure 2). On the body skin, the patient showed some petechiae (Figure 3).

Figure 1. Initial aspect of gingival mucosa. The mucosa was presenting signals associated with gingivitis, edema and spontaneous bleeding.

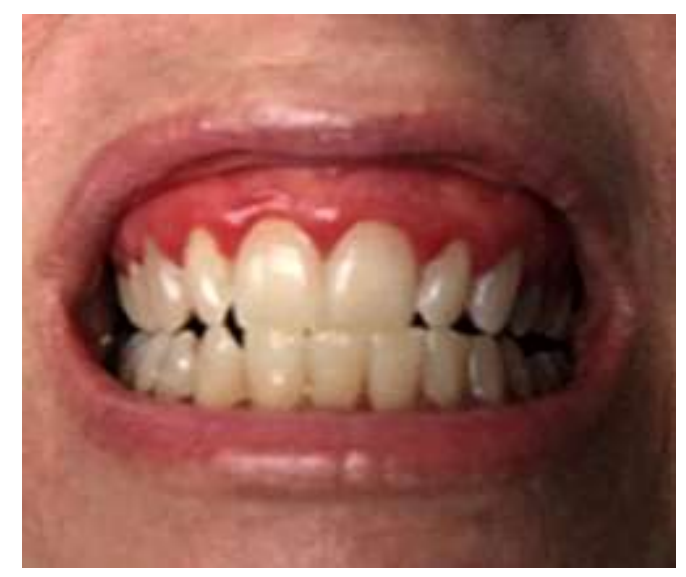

Source: Authors.

Figure 2. Panoramic image presented some bone reabsorption compatible to the age and systemic condition.

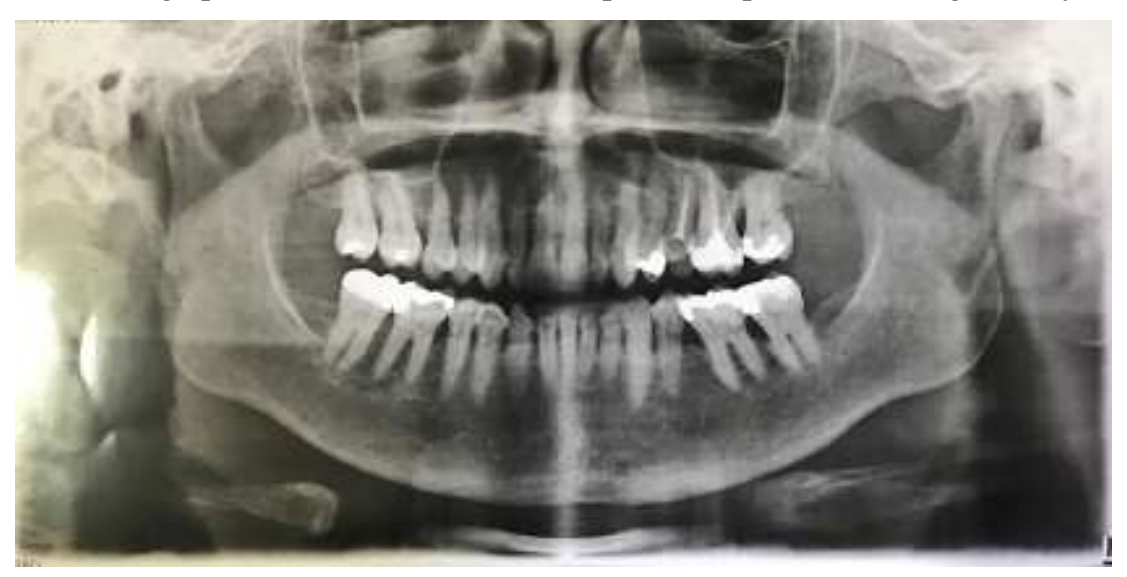

Source: Authors. 
Figure 3. Petechiae present in patient's belly and arms.

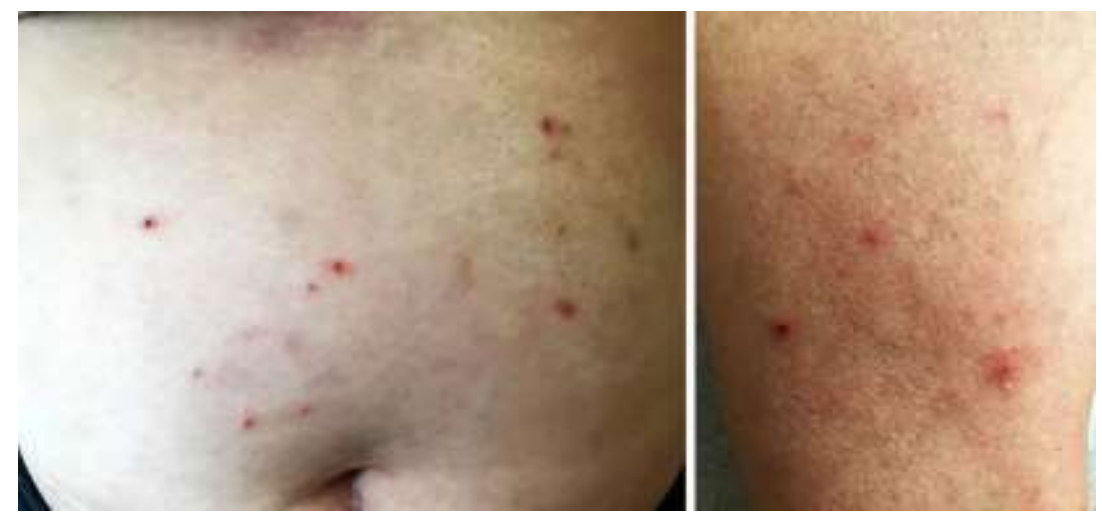

Source: Authors.

Due to the hypothesis of some autoimmune dermatological impairment, the patient was referred to a dermatologist. The dermatologist asked for several exams, including the vitamin $\mathrm{c}$ dosages. The results for vitamin $\mathrm{C}$ showed less than 0,25 $\mathrm{mg} / \mathrm{dL}$ (reference interval 0,4 to $2,0 \mathrm{mg} / \mathrm{dL}$ ), and the scurvy diagnosis was made. Initially, treatment started with $2 \mathrm{~g}$ of vitamin C per day. One month later, the level of vitamin $C$ was still low $(1,4 \mathrm{mg} / \mathrm{dL})$, and, although milder, still presented bleeding and gingivitis.

Almost two months after starting treatment, the patient was admitted to the hospital to take intravenous vitamin C because of the persistent body ache and slow general improvement. After five days, she was discharged from the hospital and reached normal serological levels of vitamin $\mathrm{C}$. The patient felt more willing, with considerable reduction in pain and oral signs (Figure 4). About a month later, the patient was diagnosed with osteoporosis and started using denosumab do treat this condition.

Figure 4. After 1 month of Vitamin C supplementation. Although the gingiva presented some hyperplasia pattern, erythema nor spontaneous bleeding, were observed.

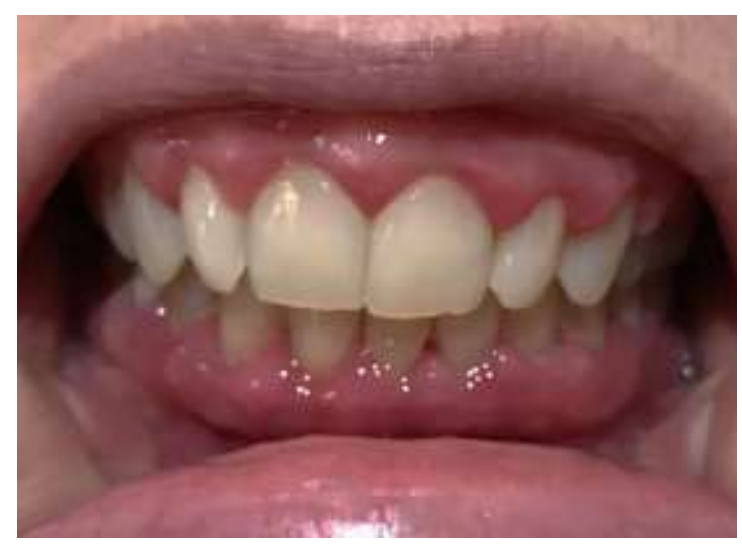

Source: Authors.

\section{Discussion}

When a patient presents scurvy in the XXI century, the first thought is about their diet habits, mostly concerned with fruits and vegetables intake (Maxfield and Crane, 2020). In its case, although the patient presented several food allergies, she presented a good diet prescribed by a nutritionist. Similarly, Li et al (2008), reported a clinical case about a 48-year woman who had several food restrictions (vegetables and fruits) and gingival hypertrophy. Due to vitamin dosage and the history of a 
poor diet in fruits and vegetables, the patient was diagnosed with scurvy. The gingival hyperplasia is reduced with vitamin $\mathrm{C}$ replacement (Li et al., 2008).

In the absence of other harmful habits, like alcohol consumption, the next suspicion is about a secondary disease or associated autoimmune condition that is hindering the absorption of ascorbic acid (Maxfield and Crane, 2020). Other authors showed a clinical case about scurvy in pediatric liver transplant patient submitted to hemodialysis. The patient symptoms included bone pain, ecchymosis, and mucosal bleeding. The symptoms when analyzed together (systemic or local, as in the oral mucosa) can help in the diagnostic hypothesis of scurvy (Samont et al., 2008; Crist and Sorg, 2014).

Lupus was not directly related to the impaired absorption of vitamin $\mathrm{C}$ in the literature. Vitamin deficiency is associated with more severe lupus activity, leading to an increased inflammatory state, deregulating the autoimmune factor, and exacerbating symptoms like fatigue and generalized body ache (Constantin et al., 2019). Besides that, ascorbic acid is known to be necessary for the formation and maintenance of bone mass, but the mechanisms involved in these processes are still unclear (Lai et al., 2017). So, the lack of vitamin C is linked to osteoporosis and could accelerate the standard process in lupus due to prolonged glucocorticoid intake to control autoimmune response (Morel, 2017; Do Amarante et al., 2008).

Vitamin supplementation, including vitamin $\mathrm{C}$, is highly indicated to patients with lupus: a maximum dose of $1 \mathrm{~g}$ per day or in combination with vitamin E. Moreover, a diet rich in vitamin C sources, like orange juice, tangerine, papaya, and broccoli, must be indicated, according to patient food intake limitations. The acid ascorbic is an important antioxidant, capable of reducing inflammation and antibody levels and preventing cardiovascular complications (Constantin et al., 2019).

The scurvy diagnostic is difficult due to the non-specific symptoms, but is not a difficult condition to be treated (Japatti et al., 2013); generally, the condition normalizes after three months of vitamin C supplementation (Maxfield and Crane, 2020). Since vitamin deficiency until the diagnosis, associated with other systemic conditions, intravenous ascorbic acid can be necessary to increase the levels more quickly due to severe symptoms and hemorrhage risk (Popovich et al., 2009).

\section{Final Considerations}

This case brought up for discussion the necessity of a complete checkup, including the vitamin levels dosage, on the diagnosis process. A complete nutritional history and a trained professional are essentials to the early diagnosis (Popovich et al., 2009). Moreover, dentists have importance on the early diagnosis since scurvy presents oral findings frequently mistaken with other more common conditions, like gingivitis or autoimmune dermatological response.

New researches in this area, mainly in periodontics, should request vitamins dosages to establish the relation between avitaminosis and gingival and periodontal diseases, regarding severity and speed of disease progression, looking for an optimized diagnosis and treatment.

\section{References}

Gutierrez, G. A. \& Martinez-Mier, E. A. (2020). Chapter 6: Vitamins and oral health. In: Monographs in Oral Science. S. Karger AG. Monogr Oral Sci. 28:5967. $10.1159 / 000455372$.

Semba R. D. (2012). The discovery of the vitamins. Int J Vitam Nutr Res. 82(5):310-5.

Maxfield, L. \& Crane, J. (2020). Vitamin C Deficiency (Scurvy). Stat Pearls.

Alvares, O., \& Siegel, I. (1980). Permeability of gingival sulcular epithelium in the development of scorbutic gingivitis. J Oral Pathol Med. 10(1):40-8.

Kern, M. \& Gardner, J. M. (2020). Mucocutaneous Manifestations of Scurvy. N Engl J Med. 382:e56.

Touyz, L. Z .G. (1984). Vitamin C, oral scurvy and periodontal disease. Sou Afric Med J. (65):838-42.

Callus, C. A., Vella, S., \& Ferry, P. (2018). Scurvy is Back. Nutr Metab Insights. 11:117863881880909.

Ceglie, G., Macchiarulo, G., Marchili, M. R., Marchesi, A., Aufiero, L. R., Camillo, C. D., \& Villani, A. (2019). Scurvy: still a threat in the well-fed first 
Research, Society and Development, v. 10, n. 12, e344101220569, 2021

(CC BY 4.0) | ISSN 2525-3409 | DOI: http://dx.doi.org/10.33448/rsd-v10i12.20569

world? Arch Dis Child. 104(4):381-383.

Shaikh, H., Faisal, M. S., \& Mewawalla, P. (2019). Vitamin C deficiency: rare cause of severe anemia with hemolysis. Int J Hematol. 109(5):618-21.

Morel, L. (2017). Immunometabolism in systemic lupus erythematosus. Nat Rev Rheumat. 13:280-90.

Likhitweerawong N., Boonchooduang N., Morakote W., \& Louthrenoo O. (2021). Scurvy mimicking as systemic lupus erythematosus. BMJ Case Rep. 21; 14(6):e242958.

Pereira, A. S. et al. (2018). Metodologia da pesquisa científica. UFSM.

Li, R., Byers, K., \& Walvekar, R. R. (2008). Gingival hypertrophy: a solitary manifestation of scurvy. Am J Otolaryngol - Head Neck Med Surg. 29(6):426-8.

Samonte V. A., Sherman P. M., Taylor G. P., Carricato M. N., Fecteau A., Ling S. C., et al. (2008). Scurvy diagnosed in a pediatric liver transplant patient awaiting combined kidney and liver retransplantation. Pediatr Transplant. 12(3):363-7.

Crist, T. A., \& Sorg, M. H. (2014). Adult scurvy in New France: Samuel de Champlain's “Mal de la terre" at Saint Croix Island, 1604-1605. Int J Paleopathol. 5:95-105.

Constantin, M. M., Nita, I. E., Olteanu, R., Constantin, T., Bucur, S., Matei, C., et al. (2019). Significance and impact of dietary factors on systemic lupus erythematosus pathogenesis (Review). Exp Ther Med. 17(2):1085-90.

Lai, C. W., Chen, H. L., Tu, M. Y., Lin, W. Y., Röhrig, T., Yang, S. H., et al. (2017). A novel osteoporosis model with ascorbic acid deficiency in Akr1A1 gene knockout mice. Oncotarget. 8(5):7357-69.

Do Amarante, F., De Souza, S. S., Borges, V., \& Feldman, C. J (2008). Study of the bone mineral density in patients with systemic lupus erythematosus before and after glucocorticoid treatment. Radiol Bras. 41(4):259-62.

Japatti, S. R., Bhatsange, A., Reddy, M., Chidambar, Y. S., Patil, S., \& Vhanmane, P. (2013). Scurvy-scorbutic siderosis of gingiva: A diagnostic challenge A rare case report. Dent Res J (Isfahan). 10(3):394-400.

Popovich D., McAlhany A., Adewumi A. O., \& Barnes M. M. K. (2009). Scurvy: Forgotten But Definitely Not Gone. J Pediatr Heal Care. $23(6)$ :405-15. 